\title{
The Impact of Company Size, Asset Structure and Profitability on Capital Structure of the Automotive Sector Companies Listed in Indonesia Stock Exchange
}

\author{
Abid Djazuli \\ Universitas Muhammadiyah Palembang \\ E-mail: abid_djazuli01@gmail.com \\ Choiriyah Choiriyah \\ Universitas Muhammadiyah Palembang \\ E-mail: choiriyahmp@yahoo.co.id
}

Novita Sari Anggraini

Universitas Muhammadiyah Palembang

Received: March 1, 2019 Accepted: April 23, $2019 \quad$ Published: April 23, 2019

doi:10.5296/jmr.v11i2.14473 URL: https://doi.org/10.5296/jmr.v11i2.14473

\begin{abstract}
This research's purpose is to analyze the influence of firm size, asset structure and the profitability toward capital structure in automotive sector companies listed on the Indonesia stock exchange (BEI). The sample of this research used purposive sampling technique in line with criteria of automotive sector manufacturing company listed on BEI and publish the result of financial report and present the data completely including data from the variables in the research period (June 2012- July 2017), so it has 7 companies as the sample. To analyze the data, the researcher used multiple linear regression. The result of this research showed that there was no significant influence of firm size to capital structure. There was significant influence of asset structure to capital structure. There was no significant influence of profitability to capital structure. There was significant influence of firm size, asset structure and profitability toward capital structure.
\end{abstract}

Keywords: Company size, asset structure, profitability, capital structure 


\section{Introduction}

Economic activity is increasingly advanced and the hope of surviving and developing in the midst of intense competition in the business world makes companies have to strive to be able to achieve the company's main goals. According to Brigham and Houston (2011) which states that developing companies need capital that can come from debt or equity which can encourage businesses to try to improve the activities of their companies. One aspect that experienced rapid development was an automotive company listed on the Indonesian stock exchange. This company is one of the developing companies in Indonesia that can provide a large income for the State.

According to Helvi (2015) which states that in the Capital Market Law No. 8 of 1995 which states that capital markets are activities related to public offerings and securities trading and public companies related to securities. The Indonesian capital market is the Indonesia Stock Exchange (IDX). The existence of the capital market in Indonesia is an alternative source of funds for the company and for investors such as those that occur in the Stock Exchange where there are trading shares of companies that have gone public where companies conducting investment activities aim to increase the wealth of investors. Investment in the capital market is closely related to the results and risks, therefore investors must pay attention to several outcome and risk indicators as investment considerations before making a decision. One such indicator is the capital structure which is a balance between the use of loan capital consisting of permanent short-term debt and long-term debt and long-term debt with own capital consisting of preferred shares and ordinary shares. In determining the capital structure, companies need to consider and pay attention to the various variables that influence it because directly the capital structure decisions will affect the condition and value of the company and determine the company's ability to survive and develop.

The development of the automotive sector in the last few years has been quite volatile. This development can be seen from the growth and development of companies engaged in the Automotive sector industry as well as emerging new companies operating in the market. Producers of the Automotive Sector face severe challenges to increase sales in the international market. Automotive business competition is becoming increasingly heavy. Republika (2017) reports that the growth of the Automotive Sector industry continues to experience ups and downs with challenges faced both from within and outside the country. Industrial development continues to increase followed by high logistics costs and poor export supporting infrastructure and high labor costs and electricity tariffs. In 2017 the total capacity of car production in Indonesia is 2.2 million units per year but the capacity utilization has dropped to $55 \%$ in 2017 because the expansion of domestic production capacity is not in line with the growth of domestic and foreign governments for Indonesian-made cars. In the midst of various kinds the crush, the component industry carries out production operational efficiency where if automotive manufacturers maintain the level of profitability, it will further pressure the domestic component industry.

The tendency to use capital will also be greater due to the large number of large companies that need large funds to support their operations. One alternative to meeting these funding 
needs is with foreign capital if the capital is insufficient. The greater the size of the company a company, the greater the amount of assets held and the more debt used as a source of corporate funding.

Asset structure is a comparison between fixed assets and total assets owned by a company in determining the amount of fund allocation for each component of assets. The higher the asset structure of the company, the higher the company's ability to secure long-term debt. Companies with high asset structure will tend to choose to use external funds or debt to fund their capital needs.

Profitability is one of the factors that influence the capital structure where profitability shows the company's ability to generate profits from various company activities through a number of policies and decisions made by the company during a certain period. The results of the Putri (2012) study of the impact of profitability on capital structure found a positive impact on profitability on capital structure but were not significant. While the asset structure and size of the company have a positive and significant effect on the capital structure of food and beverage companies listed on the Indonesia Stock Exchange. While the results of Lessy (2016) show that the size of the company does not affect the capital structure. Another variable in this study is liquidity, profitability and asset structure where the three variables have a negative and significant effect on the capital structure.

The results of Bhawa's research (2015) show that the size of the company has a negative but not significant effect on capital structure and liquidity has a significant positive effect on capital structure and profitability has a significant negative effect on capital structure while business risk has a positive but not significant effect on the capital structure pharmaceutical company listed on the Indonesia Stock Exchange. The results of Priambodo's study (2014) found that the asset structure had a positive but not significant effect on the capital structure and the rate of sales growth had a positive but not significant effect on capital structure and profitability which had a negative and significant effect on capital structure. The research results of Yudiaatmaja (2016) show that, the size of the company the size of the company and the positive and significant profitability of the capital structure. Based on the background of the above problems, it is interesting to examine the Effect of Company Size, Asset Structure and Profitability on Capital Structure in Automotive Sector Companies Listed on the Indonesia Stock Exchange (IDX).

\section{Literature Review}

Capital structure is the composition of the company's capital which shows the portion between sources of debt and equity. Capital structure is measured using three indicators, namely leverage, debt to equity, and collateralizable assets. Leverage reflects the use of sources of funds originating from long-term debt (foreign capital) which creates a fixed burden for the company, such as interest expense. The value of this indicator is determined using a long-term debt to total assets ratio (Sugeng, 2009). According to Mahendra (2011) capital structure is permanent funding consisting of long-term debt, preferred stock and shareholder capital. The company's capital structure generally consists of several components, namely (1) Long-term debt, which is a debt with a repayment period of more than 10 years. 


\section{Mll Macrothink}

Journal of Management Research

ISSN 1941-899X

2019, Vol. 11, No. 2

This component consists of mortgage debt and bonds; (2) Shareholder capital consisting of preferred shares and ordinary shares. From this view, it can be concluded that the capital structure is a permanent expenditure that reflects the balance between long-term debt with own capital (Riyanto, 2011).

According to Riyanto (2011), own capital is basically capital originating from the owner of the company and which is embedded in the company for a period of time. Therefore, capital itself in terms of liquidity is a long-term fund that is not certain time. Own capital originating from internal sources is the profit generated by the company. While own capital originating from external sources is capital that comes from the owner of the company. Foreign capital (Riyanto, 2011) is capital originating from outside the company that is temporary in the company and for the company in question the capital is debt which in time must be repaid. Debt consists of short-term debt, medium-term debt and long-term debt. Short-term debt (Riyanto, 2011) is foreign capital with a maximum period of one year in which most of the short-term debt consists of trade credit needed to be able to carry out its business. Medium-term debt is debt with a term of more than one year and less than 10 years in which the debt is adjusted to the business funding needs. While long-term debt is a debt that is more than 10 years in duration and is used to fund the company's expansion and modernization of the company.

The size of the company is seen from the amount of equity value, company value, or total assets of a company. The bigger the company, the greater the tendency to use foreign capital. This is because large companies need large funds to support other operations and one alternative is to use foreign capital if their own capital is insufficient. Company size is a characteristic of a company in relation to the company's structure. The size of a company is one of the benchmarks used by an investor. Large and established companies will have easy access to the capital market, while new companies and those who are still small will experience many difficulties in accessing the capital market. The size of the company is a consideration for investors in investing.

Assets are all resources and owned by the company to be used in its operational activities. A company generally has two types of assets, namely current assets and fixed assets. These two asset elements will form the asset structure. The asset structure of a company will appear in the left side of the balance sheet. Asset structure is also called asset structure or wealth structure. Asset structure (Syamsudin, 2009) relates to the determination of the size of the fund allocation for each component of assets, both in current assets and fixed assets. From the above understanding can be concluded that the structure of assets is a comparison between fixed assets and total assets that can determine the amount of fund allocation for each component of assets.

Current assets are part of the asset structure. Current assets generally have a relatively short age or turnover rate which is usually less than one year. Fixed assets have a life span of more than one year, so that investment in fixed assets is a long-term investment. For companies, fixed assets absorb a large portion of the capital invested in the company. However, this does not apply absolutely to all types of companies. The number of fixed assets in the company is 
also influenced by the nature or type of production processes carried out.

Profitability ratio (Kasmir, 2014) is a ratio used to assess a company's ability to seek profits. This ratio also provides information about the size of the level of management effectiveness of a company. This is indicated by profits generated from sales and investment income. The use of profitability ratios can be done by using a comparison between various components in the financial statements, especially the financial statements of the balance sheet and income statement. Measurements can be made for several operating periods. The goal is to see the development of the company in a certain period of time whether the company has decreased or increased, so the company can find the cause.

\section{Research Method}

Research design is a work guideline so that research can run effectively and efficiently. Design is not only useful for research implementers but also useful for all involved in the research activities. Research design can be arranged based on the formulation of the problem and the hypothesis to be tested. Quantitative research methods can be interpreted as research methods based on the philosophy of positivism, which is used to examine a population or a particular sample. The sampling technique is generally done randomly where data collection uses research instruments. Data analysis is quantitative in order to test the hypotheses that have been determined (Sugiyono, 2012). Data collection techniques used in this study are documentation using data in the form of balance sheets and income statements during the June 2012 - July 2017 period.

The dependent variable is the capital structure that is used to measure the debt with equity in automotive sector companies in BEI. The independent variables are the size of the company (x1), the assets structure (x2) and the profitability ratio (x3). The natural logarithm of total assets is used as the size of the company. The ratio of fixed assets to total assets is used as the assets structure benchmark and the ratio of profita after tax to total asset is used as profitability indicator.

The research sample was determined by purposive sampling method where sampling was based on certain criteria that were adjusted to the research objectives. Based on the criteria, the number of samples in the study were 7 companies from 11 Automotive Sector companies on the Indonesia Stock Exchange. To examine the effect of firm size, asset structure and profitability on capital structure, below is the equation model employed.

$$
Y=\mathrm{a}+b_{1} X_{1}+b_{2} X_{2}+b_{3} X_{3}+\mathrm{e}
$$

where:

$\mathrm{Y} \quad=$ Capital Structure

a $, b_{1}, b_{2}, b_{3}=$ Multiple linear regression coefficient

$X_{1} \quad=$ Company Size

$X_{2} \quad=$ Asset Structure 


$$
\begin{array}{ll}
X_{3} & =\text { Profitability } \\
e & =\text { Error Term }
\end{array}
$$

\section{Findings and Discussions}

Below is the equation model for the effect of firm size (X1), Asset Structure (X2) and profitability (X3) on Capital Structure (Y):

$$
\mathrm{Y}=551.387-12.387 \mathrm{X}_{1}+1.816 \mathrm{X}_{2}-4.868 \mathrm{X}_{3}
$$

ANOVA $^{\text {a }}$

\begin{tabular}{|l|l|l|l|l|l|}
\hline Model & Sum of Squares & df & Mean Square & F & Sig. \\
\hline 1 Regression & 398528.979 & 3 & 132842.993 & 3.552 & $.026^{\mathrm{a}}$ \\
Residual & 1159357.167 & 31 & 37398.618 & & \\
Total & 1557886.146 & 34 & & & \\
\hline
\end{tabular}

a. Dependent Variable: Y

b. Predictors: (Constant)X3, X2, X1

From the table above, it can be seen that the firm size, asset structure, and profitability have a significant effect on capital structure. This finding is inline with the research finding conducted by Putri (2012), Lessy (2016), Bhawa (2015), Priambodo (2014), Yudiaatmaja (2016). The higher the capital structure of the company, the better the value of the company. If the company's capital structure is high, it can affect the value of the company by means of capital structures obtained from internal or external can determine the value of a company.

\section{Coefficients $^{\mathrm{a}}$}

\begin{tabular}{|l|r|r|r|r|r|}
\hline \multirow{2}{*}{ Model } & \multicolumn{2}{|c|}{$\begin{array}{c}\text { Unstandardized } \\
\text { Coefficients }\end{array}$} & \multicolumn{2}{c|}{$\begin{array}{c}\text { Standardized } \\
\text { Coefficients }\end{array}$} & \multirow{2}{*}{} \\
\cline { 2 - 4 } & \multicolumn{1}{|c|}{ B } & Std. Error & \multicolumn{1}{|c|}{ Beta } & \multicolumn{1}{c|}{ t } & \multicolumn{1}{c|}{ Sig. } \\
\hline (Constant) & 1,990 &, 440 & & 4,520 &, 000 \\
X1 & -12.387 & 4.665 & -.572 & -2.655 & .012 \\
X2 & 1.816 & .845 & .491 & 2.148 & .040 \\
X3 & -4.868 & 3.394 & -.264 & -1.435 & .161 \\
\hline
\end{tabular}

a. Dependent Variable: Capital Structure

From the table above, it can be seen that the size of the company have a significant and negative effect on capital structure in the automotive sector companies listed on the Indonesia Stock Exchange (IDX) period of June 2012-July 2017. The findings of this research are in line with the study of Priambodo (2014), and Putri (2012) that the asset structure has a positive and significant effect on capital structure. This indicates the higher the structure of 
the company's assets, the company will tend to reduce the use of external funding. The use of external funding sources or debt is only used when internal funding is insufficient.

Moreover, it can be seen that the profitability have a negative effect on the capital structure of automotive sector companies listed in Indonesia Stock Exchange (IDX) during the period of juni 2012-july 2017 but not significant. The findings of this study are in line with the results of Yudiaatmaja (2016) study that profitability has a negative effect on capital structure. The higher the rate of Return on Assets the company will be the better the condition of the company. If the company's ROA is high, then the company will be able to guarantee the survival of the shareholders and also be able to pay off its debts both short-term debt and long-term debt. The lower the company's ROA, the more difficult it will be to guarantee the survival of shareholders. This needs to be watched out in carrying out the company's operations, so that the profits obtained can be used as well as possible.

\section{Conclusion}

It can be concluded that tere is a significant effect of firm size, asset structure and profitability to capital structure in automotive sector companies listed in Indonesia Stock Exchange (BEI). For investors in taking stock investment decisions in the automotive sector companies should consider the structure of assets because it simultaneously affect the capital structure. This is reinforced by the results of research that mentions the structure of assets significantly affect the capital structure of the company. For the management of automotive sector companies in taking fundamental economic decisions should strive to produce a firm size and profitabiloitas high. For further research related factors affecting capital structure in order to enlarge the study population or can make comparisons with other sectors.

\section{References}

Brigham, E.F., \& Houston, D.J.F. (2011). Dasar-Dasar Manajemen Keuangan. Jakarta: Salemba Empat.

Lessy, D.A. (2016). Pengaruh ukuran perusahaan, likuiditas, profitabilitas dan struktur aktiva terhadap struktur modal pada perusahaan manufaktur yang terdaftar di Bursa Efek Indonesia. Tesis: Negeri Yogyakarta. Diunduh dari: https://eprints.uny.ac.id/39209/

Yudiaatmaja, F. (2016). Pengaruh ukuran perusahaan dan profitabilitas terhadap struktur modal pada perusahaan property and real estate yang terdaftar Di Bursa Efek Indonesia. Jurnal Manajemen, 4.

Bhawa, I.B.M.D. (2015). Pengaruh ukuran perusahaan, likuiditas, profitabilitas dan resiko bisnis terhadap struktur modal pada perusahaan farmasi yang terdaftar Di Bursa Efek Indonesia. Jurnal Manajemen, 4(7).

Kasmir. (2014). Analisis Laporan Keuangan. Jakarta: Raja Grafindo Persada.

Putri, M.E.D. (2012). Pengaruh profitabilitas, struktur aktiva dan ukuran perusahaan terhadap struktur modal pada perusahaan manufaktur sektor industry makanan dan minuman BEI. Jurnal Manajemen, 1(1). 
Riyanto, B. (2011). Dasar-Dasar Pembelajaran Perusahaan. Yogyakarta: BPFE

Sugeng, B. (2009). Pengaruh struktur kepemilikan dan struktur modal terhadap kebijakan inisiasi dividen di Indonesia. Jurnal Ekonomi dan Bisnis, 14.

Sugiyono (2012). Metode Penelitian Bisnis. Bandung: Alfa Beta.

Syamsudin, L. (2009). Manajemen Keuangan Perusahaan. Jakarta: Raja grafindo persada.

Priambodo, T.J. (2014). Pengaruh struktur aktiva, tingkat pertumbuhan penjualan dan profitabilitas terhadap struktur modal pada perusahaan tekstil dan garmet yang listing di Bursa Efek Indonesia. Jurnal Administrasi Bisnis, 9(1). https://doi.org/10.24815/jdab.v1i2.3633

\section{Copyright Disclaimer}

Copyright for this article is retained by the author(s), with first publication rights granted to the journal.

This is an open-access article distributed under the terms and conditions of the Creative Commons Attribution license (http://creativecommons.org/licenses/by/3.0/). 